\title{
BERMASALAH DENGAN ANALISIS JAMINAN (Studi Kasus di PT Bank Syariah Mandiri Cabang Padangsidimpuan)
}

\author{
Arti Damisa \\ Institut Agama Islam Negeri Padangsidimpuan \\ Jalan T. Rizal Nurdin Km. 4,5 Sihitang, Padangsidimpuan \\ Email : afdhalhamonanganharahap@yahoo.com
}

\begin{abstract}
Abstrak,
Pembiayaan untuk pengusaha mikro di PT Bank Syariah Mandiri Cabang Padangsidimpuan adalah pembiayaan dengan akad murabahah. Nasabah pembiayaan murabahah merupakan pengusaha mikro yang sewaktu-waktu tidak dapat melunasi kewajiban dengan alasan tertentu. Tujuan penelitian ini untuk mengetahui cara penyelamatan dan penyelesaian pembiayaan bermasalah dengan analisa jaminan di PT Bank Syariah Mandiri Cabang Padangsidimpuan. Penelitian ini menggunakan jenis penelitian kualitatif dengan pendekatan deskriptif. Adapun teknik pengumpulan data dalam penelitian ini melalui wawancara, observasi dan dokumentasi. Berdasarkan hasil penelitian yang dilakukan di lapangan, menunjukkan bahwa proses penyelamatan dan penyelesaian pembiayaan bermasalah dengan analisis jaminan pada PT Bank Syariah Mandiri Cabang Padangsidimpuan diselesaikan dengan 2 (dua) tahapan. Pertama, apabila nasabah sudah masuk pada kategori kolektibilitas empat dan lima, maka PT Bank Syariah Mandiri Cabang Padangsidimpuan akan memberikan surat pemberitahuan I, II dan III. Kedua, apabila tidak ada konfirmasi setelah surat pemberitahuan III, maka nasabah akan berurusan langsung dengan Account Maintenance. Walaupun sudah dinilai bermasalah, PT Bank Syariah Mandiri Cabang Padangsidimpuan tidak langsung melelang jaminan begitu saja. PT Bank Syariah Mandiri Cabang Padangsidimpuan masih memberikan kelonggaran waktu kepada nasabah untuk menjual sendiri jaminannya sebelum dilelang oleh bank.
\end{abstract}

Kata kunci: Penyelamatan, Penyelesaian, Pembiayaan Bermasalah, Murabahah

\begin{abstract}
,
Financing for micro entrepreneurs in PT Bank Syariah Mandiri Padangsidimpuan Branch is financing with a murabahah contract. Murabahah financing customers are micro entrepreneurs who cannot pay their obligations at any time. The purpose of this research is to find out how to save and settle problem financing with guarantee analysis at PT Bank Syariah Mandiri Padangsidimpuan Branch. This study uses qualitative research with a descriptive approach. This study obtained data using secondary data by reviewing books that became reference sources and primary data from the informants of PT Bank Syariah Mandiri Padangsidimpuan Branch in accordance with the title of the researcher. The data collection techniques in this study through interviews, observation and documentation. Based on the results of research conducted in the field, shows that the process of rescue and completion of financing problems with the analysis of guarantees at PT Bank Syariah Mandiri Padangsidimpuan Branch completed with 2 (two) stages. First, if the customer has entered the four. Second, if there is no confirmation after notification letter III, the customer will deal directly with Account Maintenance. and five collectibility categories, then the PT Bank Syariah Mandiri Padangsidimpuan Branch will provide notification letters I, II and III. Although it has been considered problematic, PT Bank Syariah Mandiri Padangsidimpuan Branch did not immediately auction guarantees. PT Bank Syariah Mandiri Branch of Padangsidimpuan still gives customers time to sell their own guarantees before being auctioned by the bank.
\end{abstract}

Keywords: Rescue, Settlement, Problem Financing, Murabahah 
PROSES PENYELAMATAN DAN PENYELESAIAN PEMBIAYAAN BERMASALAH DENGAN

ANALISIS JAMINAN (Studi Kasus Di PT Bank Syariah Mandiri Cabang Padangsidimpuan)

Arti Damisa

\section{PENDAHULUAN}

PT Bank Syariah Mandiri kantor Cabang Padangsidimpuan hadir dengan paduan harmonisasi idealisme dengan nilai-nilai spiritual. Berdiri sejak 25 Oktober 1999 dan beroperasi 01 November 1999 sampai dengan sekarang. PT Bank Syariah Mandiri selalu memberikan kontribusi yang besar terhadap perkembangan dunia perbankan syariah saat ini. Sebagai salah satu perbankan yang berbasis Islam, PT Bank Syariah Mandiri terus mengeluarkan produk dan jasa terbaru yang dibutuhkan oleh masyarakat.

Produk dan jasa yang ditawarkan oleh PT Bank Syariah Mandiri yaitu pembiayaan dan penghimpunan. Kegiatan menghimpun dana dilakukan melalui tabungan, giro dan deposito. Sedangkan dalam penyaluran dana dilakukan dalam bentuk modal kerja, investasi dan konsumer.

Pembiayaan adalah kegiatan bank untuk menyalurkan dana kepada orang yang kekurangan dana untuk keperluan tertentu. Pembiayaan kepada masyarakat tidak diberikan secara mudah, karena harus melalui beberapa prosedur dari pihak bank (Karim, 2011). Adapun pembiayaan yang diberikan kepada masyarakat secara umum dilakukan dalam tiga akad utama yaitu Al-Murabahah, Al-Musyarakah, Al-Mudharabah. Namun, yang lazim dilakukan oleh Bank Syariah Mandiri adalah akad murabahah dan musyarakah (Sutedi, 2009).

Berdasarkan hasil wawancara dengan Micro Financing Sales (sales pembiayaan mikro) menyatakan bahwa khusus untuk pembiayaan pada warung mikro, pembiayaan dengan akad jual beli murabahah lebih diminati nasabah pengusaha mikro. Untuk membeli mesin, peralatan dan perlengkapan yang dibutuhkan nasabah yang akan berfungsi sebagai penunjang usaha mereka. Pembiayaan pada warung mikro Bank Syariah Mandiri tidak sertamerta memberikan pembiayaan tanpa memenuhi prosedur yang telah ditetapkan oleh Bank Syariah Mandiri (Andri Syahputra, Micro Financing Sales BSM Cabang Padangsidimpuan).

Jaminan yang diterima oleh Bank Syariah Mandiri khusus untuk pengusaha mikro adalah akta tanah, rumah atau kebun yang sudah dilegalisasi oleh pihak kantor pertanahan dan ada sertifikat dari Pejabat Pembuat Akta Tanah (PPAT) dan sejenisnya. Jaminan seperti Surat Tanda Nomor Kenderaan (STNK) dan Buku Pemilik Kenderaan Bermotor (BPKB) dahulu juga diperbolehkan.

Namun untuk sekarang Bank Syariah Mandiri tidak menggunakan jaminan seperti itu, karena sudah banyak pembiayaan yang menggunakan jaminan tersebut dalam pembiayaan Leasing. Leasing memberikan pembiayaan dengan cepat hanya dengan jaminan STNK dan BPKB. Agar tidak kalah dalam persaingan seperti itu, Bank Syariah Mandiri hadir dengan terobosan produk-produk jitu dan terbaru.

Salah satu dari pemenuhan prosedur tersebut agar calon debitur mendapatkan pembiayaan yang diinginkan yaitu dengan memberikan jaminan kepada pihak bank. Bukan 
untuk mempersulit nasabah dalam hal pembiayaan, tetapi untuk meyakinkan pihak bank dalam pemberian pembiayaan dengan nyaman kepada nasabah. Selain itu, jaminan juga berfungsi untuk mengantisipasi risiko yang ada. Salah satunya adalah meminimalisir resiko yang ada seperti character risk(Karim, 2009).

Apabila debitur gagal melunasi angsuran dan tidak dapat memberikan margin, bank berhak mengambil proyek usaha. Namun, jika terjadi kerugian yang sangat besar maka bank syariah dapat menguasai barang jaminan. Terbukti untuk tahun 2015 pembiayaan bermasalah untuk akad murabahah adalah sebanyak 98 nasabah dan tahun 2016 sebanyak 132 nasabah (Samsul Bahri, Account Maintenance BSM Cabang Padangsidimpuan).

Setelah adanya pemaparan di atas, peneliti merasa tertarik untuk membahas lebih lanjut tentang hal tersebut. Sehingga peneliti membuat suatu penelitian yang berjudul "Proses Penyelamatan dan Penyelesaian Pembiayaan Bermasalah dengan Analisis Jaminan (Studi Kasus di Bank Syariah Mandiri Cabang Padangsidimpuan)".

\section{TINJAUAN TEORITIK \\ Jaminan Pembiayaan}

Menurut Undang-Undang Republik Indonesia Nomor 21 Tahun 2008 tentang Perbankan Syariah Pasal 1 angka (30) "Agunan adalah jaminan tambahan baik berupa benda bergerak maupun benda tidak bergerak yang diserahkan oleh pemilik agunan kepada Bank Syariah dan/ Unit Usaha Syariah guna menjamin pelunasan kewajiban nasabah penerima fasilitas."

Jaminan pembiayaan menurut Veithzal Rivai dan Andria Permata sebagai hak dan kekuasaan atas barang jaminan yang diserahkan oleh debitur kepada lembaga keuangan guna menjamin pelunasan utangnya apabila pembiayaan yang diterimanya tidak dapat dilunasi sesuai waktu yang diperjanjikan dalam perjanjian pembiayaan atau addendumnya (Rivai dan Veithzal, 2008).

Pembiayaan dalam perbankan syariah atau istilah teknisnya disebut aktiva produktif, menurut ketentuan Bank Indonesia adalah penanaman dana Bank Syariah baik dalam rupiah maupun valuta asing dalam bentuk pembiayaan, piutang, qardh, surat berharga syariah, penempatan, penyertaan modal, penyertaan modal sementara, komitmen dan kontinjensi pada rekening administratif serta sertifikat wadiah Bank Indonesia (Muhammad, 2014).

\section{Landasan Hukum Jaminan Pembiayaan}

Berdasarkan Undang-Undang Republik Indonesia Nomor 21 Tahun 2008 Tentang Perbankan Syariah Pada Pasal 23 ayat 1 dan 2 menyebutkan bahwa :

a) Bank Syariah dan/ atau Unit Usaha Syariah harus mempunyai atas kemauan dan kemampuan calon Nasabah Penerima Fasilitas untuk melunasi seluruh kewajiban pada 
PROSES PENYELAMATAN DAN PENYELESAIAN PEMBIAYAAN BERMASALAH DENGAN

ANALISIS JAMINAN (Studi Kasus Di PT Bank Syariah Mandiri Cabang Padangsidimpuan)

Arti Damisa

waktunya, sebelum Bank Syariah dan/ atau UUS menyalurkan dana kepada Nasabah Calon Penerima Fasilitas.

b) Untuk memperoleh keyakinan sebagaimana dimaksud pada ayat, Bank Syariah dan/ atau UUS wajib melakukan penilaian yang seksama terhadap watak, kemampuan, modal, Agunan dan prospek usaha dari calon Nasabah Penerima Fasilitas.

Adapun Landasan Syariah Jaminan Pembiayaan terdapat dalam Al-Qur'an Surah AlBaqarah ayat 283 yang artinya: Jika kamu dalam perjalanan (dan bermu'amalah tidak secara tunai) sedang kamu tidak memperoleh seorang penulis, Maka hendaklah ada barang tanggungan yang dipegang (oleh yang berpiutang). akan tetapi jika sebagian kamu mempercayai sebagian yang lain, Maka hendaklah yang dipercayai itu menunaikan amanatnya (hutangnya) dan hendaklah ia bertakwa kepada Allah Tuhannya; dan janganlah kamu (para saksi) Menyembunyikan persaksian. dan Barangsiapa yang menyembunyikannya, Maka Sesungguhnya ia adalah orang yang berdosa hatinya; dan Allah Maha mengetahui apa yang kamu kerjakan.

Berdasarkan ayat di atas, telah dijelaskan bahwa jika sesama muslim bermu'amalah ataupun melakukan kegiatan bisnis seperti perdagangan tetapi tidak secara tunai, maka hendaklah seseorang dari mereka memberi barang tanggungan yang dalam hal ini disebut sebagai "jaminan" untuk dipegang oleh pihak lain. Adapun dilakukannya persyaratan seperti ini, apabila salah satu pihak kurang percaya kepada pihak lain.

\section{Langkah-langkah Analisis Jaminan}

\section{a. Nilai Jaminan}

Penilaian jaminan adalah tanggung jawab pejabat pembiayaan $(\mathrm{AO}=$ account officer dan $\mathrm{CRO}=$ credit recovery officer). Namun apabila dibutuhkan maka dapat ditugaskan unit kerja lain ( $L O=$ =loan officer) untuk ikut serta menilai kewajaran nilai taksasi barang jaminan. Besarnya jaminan yang harus disediakan nasabah adalah sebagai berikut:

1) Untuk pembiayaan eksploitasi biasa, nilai jaminan minimum $250 \%$ dari maksimum pembiayaan dengan rincian sebagai berikut:

a) Jaminan pembiayaan sebaiknya $150 \%$

b) Jaminan tambahan 100\% (sebesar pembiayaan yang diperoleh nasabah).

2) Untuk pembiayaan investasi nilai jaminan pembiayaan dan agunan minimum $150 \%$ dari maksimum pembiayaan (Rivai dan Veithzal, 2008).

\section{b. Prosedur Penilaian Jaminan}

Sebelum barang-barang yang tertera pada daftar barang jaminan ditetapkan nilainya, diterima dan diikat sebagai jaminan pembiayaan, perlu diperhatikan sebagai berikut:

1) Meneliti dan mempelajari kelengkapan, kebenaran dan keabsahan dokumendokumen yang diserahkan oleh nasabah sehingga diperoleh kesimpulan bahwa barang-barang itu dapat diikat secara hukum atau yuridis. Untuk meneliti keabsahan 
dari sertifikat tanah, lakukan pengecekan langsung ke Badan Pertanahan Nasional (BPN) setempat.

2) Melakukan peninjauan setempat (on the spot) untuk mengetahui dan menilai keadaan fisik barang-barang yang akan dijadikan jaminan, apakah sesuai dengan yang tercantum dalam berkas-berkas/dokumen yang ada dan keterangan serta penjelasan lain yang diberikan nasabah. Jika penilaian harga barang-barang agunan yang diserahkan kepad pihak ketiga, maka peninjauan setempat harus dilakukan bersama-sama pihak lembaga keuangan.

\section{c. Analisis Jaminan Pembiayaan}

Analisis jaminan menurut (Ikatan Bankir Indonesia, 2014) adalah bentuk evaluasi terhadap aspek collateral. Adapun analisis jaminan Menurut (Zulkifli, 2003) adalah analisis mengenai jaminan diarahkan terhadap jaminan yang diberikan. Jaminan dimaksud harus mampu meng-cover risiko bisnis calon nasabah.

Analisis dilakukan terhadap jaminan pembiayaan dan sumber keuangan lain yang dapat digunakan sebagai alternatif sumber pengembalian pembiayaan. Analisis dilakukan untuk mengetahui kecukupan nilai jaminan pemberian pembiayaan.

Adapun jenis jaminan yang dapat diterima bank, sebagai berikut:
1) Tanah
2) Bangunan
3) Kenderaan bermotor
4) Persediaan
5) Piutang dagang
6) Mesin-mesin pabrik

Pembiayaan Murabahah

\section{a. Pengertian Pembiayaan Murabahah}

Murabahah adalah akad jual beli atas barang dengan harga yang disepakati antara penjual dan pembeli, setelah sebelumnya penjual menyebutkan dengan sebenarnya harga perolehan atas barang tersebut dan besarnya keuntungan yang diperolehnya.

\section{b. Fatwa DSN MUI No. o4/DSN-MUI /IV/200o tentang Murabahah}

Ketentuan hukum dalam Fatwa DSN MUI No 04/DSN-MUI/IV/2000 tentang murabahah berisi ketentuan umum murabahah dalam bank syariah:

1) Bank dan nasabah harus melakukan akad murabahah yang bebas riba.

2) Barang yang diperjualbelikan tidak diharamkan oleh syariah Islam.

3) Bank membiayai sebagian atau seluruh harga pembelian barang yang telah disepakati spesifikasinya.

4) Bank membeli barang yang diperlukan nasabah atas nama bank sendiri, dan pembelian ini harus sah dan bebas riba. 
PROSES PENYELAMATAN DAN PENYELESAIAN PEMBIAYAAN BERMASALAH DENGAN

5) Bank kemudian menjual barang tersebut kepada nasabah degan harga jual senilai harga beli plus keuntungannya. Dalam kaitan ini bank harus memberitahu secara jujur harga pokok barang kepada nasabah befikut biaya yang diperlukan.

6) Nasabah membayar harga barang yang telah disepakati tersebut pada jangka waktu tertentu yang telah disepakati.

7) Untuk mencegah terjadinya penyalahgunaan atau kerusakan akad tersebut, pihak bank dapat mengadakan perjanjian khusus dengan nasabah.

8) Jika bank hendak mewakilkan kepada nasabah untuk membeli barang dari pihak ketiga, akad jual beli murabahah harus dilakukan setelah barang secara prinsip menjadi milik bank.

\section{c. Landasan Hukum Murabahah}

Adapun landasan hukum akad murabahah terdapat pada Al-Quran Surah AnNisaa ayat 29 yang berbunyi :

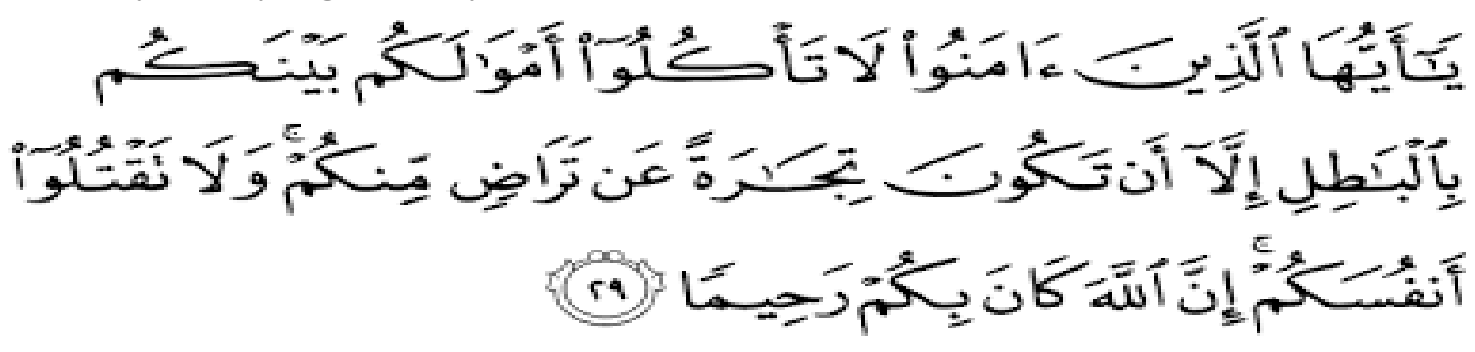

Artinya: Hai orang-orang yang beriman, janganlah kamu saling memakan harta sesamamu dengan jalan yang batil, kecuali dengan jalan perniagaan yang berlaku dengan suka sama-suka di antara kamu. Dan janganlah kamu membunuh dirimu; sesungguhnya Allah adalah Maha Penyayang kepadamu.

\section{Penyelamatan dan Penyelesaian Pembiayaan Bermasalah}

Penyelamatan pembiayaan (restrukturisasi pembiayaan) adalah istilah teknis yang biasa dipergunakan di kalangan perbankan terhadap upaya dan langkah-langkah yang dilakukan bank dalam mengatasi pembiayaan bermasalah.

Restrukturisasi pembiayaan adalah upaya yang dilakukan bank dalam rangka membantu nasabah agar dapat menyelesaikan kewajibannya, antara lain melalui penjadwalan kembali (rescheduling), persyaratan kembali (reconditioning) dan penataan kembali (resturucturing).

Bank Umum Syariah (BUS) dan Unit Usaha Syariah (UUS) dapat melakukan restrukturisasi pembiayaan terhadap nasabah yang mengalami penurunan kemampuan pembayaran dan masih memiliki prospek usaha yang baik serta mampu memenuhi kewajiban setelah restrukturisasi.

Adapun restrukturisasi yang lazim dilakukan oleh bank syariah adalah:

\section{a. Penjadwalan Kembali (Rescheduling)}

Penjadwalan kembali yaitu perubahan jadwal pembayaran kewajiban nasabah atau jangka waktunya, tidak termasuk perpanjangan atas pembiayaan yang memenuhi 
kualitas lancar dan telah jatuh tempo serta bukan juga disebabkan nasabah mengalami penurunan kemampuan membayar.

\section{b. Persyaratan Kembali (Reconditioning)}

Persyaratan kembali yaitu perubahan sebagian atau seluruh pernyataan pembiayaan tanpa menambah sisa pokok kewajiban nasabah yang harus dibayarkan kepada bank antara lain:

1) Perubahan jadwal pembayaran

2) Perubahan jumlah angsuran

3) Perubahan margin dalam pembiayaan

4) Pemberian potongan

\section{c. Penataan Kembali (Restructuring)}

Penataan kembali yaitu perubahan persyaratan pembiayaan antara lain:

1) Penambahan dana fasilitas Bank Umm Syariah

2) Konversi akad pembiayaan

3) Konversi pembiayaan menjadi Surat Berharga Syariah Berjangka Waktu Menengah

4) Konversi pembiayaan menjadi Penyertaan Modal Sementara pada perusahaan nasabah yang dapat disertai dengan rescheduling atau reconditioning

Langkah-langkah tersebut dalam pelaksanaannya dapat dilakukan secara bersamaan, misalnya pemberian keringanan jumlah angsuran disertai kelonggaran jadwal pembayaran. Adapun kualitas pembiayaan yang biasa disebut dengan istilah kollektibilitas. kollektibilitas adalah Trade Record dari nasabah dalam kewajiban pembiayaan di sebuah bank. Pembiayaan menurut kualitasnya pada hakikatnya didasarkan atas risiko kemungkinan terhadap kondisi dan kepatuhan nasabah pembiayaan dalam memenuhi kewajiban-kewajiban untuk membayar bagi hasil, serta melunasi pembiayaannya. Jadi unsur utama dalam menentukan kualitas tersebut adalah waktu pembayarannya, bagi hasilnya dan pembayaran angsuran maupun pelunasan pokok pembiayaan dan diperinci dalam lima kollektibilitas yang masingmasing memiliki definisi yang berbeda.

1) Kollektibilitas satu

Kollektibilitas satu adalah Trade Record nasabah dalam setiap kewajiban melunasi utang tidak pernah ada masalah atau sama dengan pembayaran lancar.

2) Kollektibilitas dua

Kollektibilitas dua yaitu nasabah pembiayaan sedang dalam perhatian khusus. Diperlukan komunikasi yang baik antara pihak Bank dan nasabah. Untuk menanyakan apa sebab nasabah menunggak pembayaran dan mengapa hal tersebut dapat terjadi.

3) Kollektibilitas tiga, empat dan lima 
Kollektibilitas tiga (kurang lancar), kollektibilitas empat (diragukan) dan kollektibilitas lima (macet) merupakan pemicu terjadinya NPF (Non Performing Financing) atau yang lebih dikenal dengan sebutan pembiayaan bermasalah (Suwiknyo, 2009). Jika nasabah sudah termasuk dalam 3 golongan tersebut. Maka hal tersebut yang dapat memicu pembiayaan bermasalah dalam sebuah Bank (Ikatan Bankir Indonesia, 2014).

Pembiayaan bermasalah akan berakibat kepada kerugian bank, yaitu tidak diterimanya kembali dana yang telah disalurkan maupun pendapatan bagi hasil yang dapat diterima. Artinya bank akan kehilangan kesempatan mendapatkan laba.

\section{METODE PENELITIAN}

\section{Jenis_Penelitian}

Sesuai dengan analisis dan pemaparan sebelumnya, maka penelitian ini termasuk pada penelitian kualitatif. Penelitian kualitatif adalah " penelitian yang dilakukan untuk mengetahui hasil dari sesuatu yang menjawab terhadap sesuatu hal yang bertanya tentang apa yang sesungguhnya terjadi (Bungin, 2010).”

Metode kualitatif ini digunakan karena beberapa pertimbangan. Pertama, menyesuaikan metode kualitatif lebih mudah apabila berhadapan dengan kenyataan ganda. Kedua, metode ini menyajikan secara langsung hakikat hubungan antara peneliti dan responden (narasumber). Ketiga, metode ini lebih peka dan lebih dapat menyesuaikan diri dengan banyak penajaman pengaruh bersama dan terhadap pola-pola nilai yang dihadapi.Data dalam penelitian ini dikumpulkan berupa kata-kata, gambar dan bukan angka. Data yang ada berasal dari hasil kutipan-kutipan dari buku, hasil wawancara, catatan atau memo peneliti. Maka dari itu, peneliti menggunakan penelitian dengan metode penelitian kualitatif deskriptif (Moleong, 2004).

\section{Subjek Penelitian}

Adapun subjek penelitian yang akan diteliti oleh peneliti berjumlah tiga orang dari pegawai bank syariah mandiri yaitu: Branch Operation Service Manager, Account Maintenance, Micro Analyst dan Cluster Admin Micro Banking pematang siantar 2.

Karyawan dari bank syariah mandiri yang dituju peneliti merupakan informan terkait judul penelitian. Branch Operation Service Manager adalah manajer bagian operasional bank yang mengetahui secara spesifik mengenai sejarah Bank Syariah Mandiri Cabang Padangsidimpuan dan pembiayaan apa saja yang ada di Bank Syariah Mandiri Cabang Padangsidimpuan.

Account Maintenance adalah staff pada bagian pembiayaan yang mengalami masalah dalam pelunasannya. Micro Analyst adalah karyawan Bank Syariah Mandiri yang menangani pembiayaan mikro. Nasabah yang akan mengajukan pembiayaan akan lebih dulu dianalis oleh bagian ini. Cluster Admin Micro Banking pematang siantar 2 bagian ini 
peneliti wawancara karena merupakan bagian yang sama dari Micro Analyst yaitu pembiayaan untuk mikro dan merupakan bagian area pematang siantar 2 yang ditempatkan pada Bank Syariah Mandiri Cabang Padangsidimpuan. Untuk memudahkan pembaca subjek peneliti akan terlihat pada tabel berikut:

Tabel 1

Informan Peneliti

\begin{tabular}{|c|c|c|}
\hline No & Nama & Jabatan \\
\hline 1 & Rahmat Pipin & $\begin{array}{c}\text { Branch Operation Service } \\
\text { Manager }\end{array}$ \\
\hline 2 & Ebda Gustining,As & $\begin{array}{c}\text { Chster Admin Micro Banking } \\
\text { Pematangsiantar 2 }\end{array}$ \\
\hline 3 & Ady Syahputra Nasution & Micro Analyst \\
\hline 4 & Samsul Bahri & Account Maintenance \\
\hline
\end{tabular}

\section{Sumber Data}

Peneliti dalam hal ini, memperoleh data dari bagian warung mikro dan bagian khusus pembiayaan bermasalah yang ada pada PT Bank Syariah mandiri Cab. Padangsidimpuan. Dengan melakukan semua teknik yang ada yang berarti melakukan penelitian dengan data primer. Selain data primer, peneliti juga menggunakan data sekunder yaitu dengan menelaah penelitian terdahulu dan buku-buku yang dijadikan sebagai sumber referensi.

\section{Teknik Pengumpulan Data}

Teknik pengumpulan data disesuaikan dengan bentuk sumber data dan jenis pendekatan penelitian. Untuk penelitian pustaka, pengumpulan datanya dengan menelaah buku-buku dan bahan-bahan lainnya sesuai keperluan peneliti. Adapun untuk penelitian lapangan, teknik pengumpulan datanya ialah tergantung pada pendekatan penelitian. Untuk penelitian kualitatif yang lebih utama berupa observasi dan wawancara.

\section{Teknik Penjamin Keabsahan Data}

Untuk mengetahui serta menjamin keabsahan data pada penelitian ini, peneliti menggunakan beberapa teknik menuju keabsahan penjamin keabsahan data yaitu sebagai berikut:

a. Perpanjangan keikutsertaan

Perpanjangan keikutsertaan peneliti sangat menentukan dalam pengumpulan data. Keikutsertaan tersebut tidak hanya dilakukan dalam waktu singkat, tetapi memerlukan perpanjangan keikutsertaan peneliti pada latar penelitian. Perpanjangan 
keikutsertaan peneliti akan memungkinkan peningkatan derajat kepercayaan data yang dikumpulkan. Hal tersebut terjadi karena peneliti sendiri akan banyak mempelajari mengenai data yang dikumpulkan.

Selain itu, perpanjangan keikutsertaan peneliti juga dimaksudkan untuk membangun kepercayaan para subjek terhadap peneliti dan juga kepercayaan diri peneliti sendiri atas terjadinya kemungkinan adanya pengaruh ganda seperti faktorfaktor kontekstual dan pengaruh bersama antara peneliti dan subjek yang akhirnya mempengaruhi fenomena yang diteliti (Moleong, 2004).

b. Ketekunan pengamatan

Ketekunan pengamatan bermaksud menemukan ciri-ciri dan unsur-unsur dalam situasi yang sangat relevan dengan persoalan atau isu yang sedang dicari dan kemudian memusatkan diri pada hal-hal tersebut secara rinci. Dengan kata lain ketekunan pengamatan memerlukan kedalaman peneliti terhadap faktor-faktor yang diteliti.

c. Triangulasi

Triangulasi dapat diartikan sebagai teknik pemeriksaan keabsahan data yang memanfaatkan sesuatu yang lain di luar data itu untuk keperluan pengecekan atau sebagai pembanding terhadap data itu. Dengan teknik di atas dapat peneliti simpulkan bahwa langkah utama adalah memeriksa keabsahan atau keberadaan data yang didapatkan kemudian mengambil pendapat lain tentang menganalisis data untuk menguatkan data atau informasi yang didapat tersebut tentang analisis jaminan terhadap pembiayaan bermasalah pada Bank Syariah Mandiri Cabang Padangsidimpuan.

d. Pemeriksaan sejawat melalui diskusi

Teknik ini dilakukan dengan cara mengekspos hasil sementara atau hasil akhir yang diperoleh dalam bentuk diskusi analitik dengan rekan-rekan sejawat. Teknik ini memiliki beberapa maksud sebagai salah satu teknik pemeriksaan keabsahan data. Yaitu untuk membuat peneliti tetap mempertahankan sikap terbuka dan kejujuran. Diskusi dengan sejawat ini memberikan suatu kesempatan awal yang baik untuk mulai menjajaki dan menguji hasil hipotesis yang muncul dari pemikiran peneliti.

\section{Teknik Pengolahan dan Analisis Data}

Dalam penelitian kualitatif, data dapat diolah dan analisis dengan berbagai teknik, yaitu berdasarkan masalah dan tujuannya. Adapun teknik pengolahan dan analisis data yaitu:

a. Analisis sebelum di lapangan adalah analisis yang dilakukan terhadap data hasil studi pendahuluan atau data sekunder, yang akan digunakan untuk menentukan fokus 
penelitian. Fokus penelitian ini bersifat sementara dan akan berkembang setelah peneliti di lapangan.

b. Analisis selama di lapangan Model Miles and Huberman

Setelah peneliti melakukan wawancara di lapangan terhadap objek yang peneliti tuju. Tetapi, jawaban dari hasil wawancara belum memuaskan, maka peneliti akan melanjutkan pertanyaan lagi sampai tahap tertentu.

Adapun aktivitas dalam analisis data adalah sebagai berikut:

1) Reduksi data berarti merangkum, memilih hal-hal yang pokok. Memfokuskan pada hal-hal yang penting, dicari tema dan pokoknya dan membuang yang tidak perlu.

2) Penyajian data, dalam penelitian kualitatif penyajian data bisa dilakukan dalam bentuk uraian singkat, bagan, hubungan antar kategori, flow chart dan sebagainya.

3) Penarikan kesimpulan dan verifikasi, Kesimpulan dalam penelitian kualitatif mungkin dapat menjawab rumusan masalah yang dirumuskan sejak awal. Tetapi, mungkin juga tidak karena telah dikemukakan bahwa masalah dan rumusan masalah dalam penelitian kualitatif bersifat sementara dan akan berkembang setelah penelit berada di lapangan.

\section{HASIL PENELITIAN DAN PEMBAHASAN}

\section{Jenis-Jenis Pembiayaan Pada Bank Syariah Mandiri Cabang Padangsidimpuan}

Pembiayaan pada Bank Syariah Mandiri Cabang Padangsidimpuan itu dimaksudkan sebagai pemberian dana kepada pihak nasabah untuk dipergunakan sesuai dengan kebutuhan masing-masing. Nasabah pada umumnya memilih pembiayaan berdasarkan pengetahuan mereka. Informasi dapat melalui brosur, pamphlet, rekan-rekan maupun langsung dari pihak bank itu sendiri misalnya customer service.

Terdapat beberapa pembiayaan yang ada pada Bank Syariah Mandiri Cabang Padagsidimpuan yaitu sebagai berikut:

a. Pembiayaan mikro

Pembiayaan jenis ini digunakan oleh pengusaha mikro guna menambah modal, membeli peralatan dan perlengkapan yang dianggap perlu oleh nasabah.

b. Pembiayaan Komersial (BSM Implan)

BSM Implan adalah pembiayaan konsumer dalam valuta rupiah yang diberikan oleh bank kepada karyawan tetap perusahaan yang pengajuannya dilakukan secara massal (kelompok).

c. Pembiayaan gadai dan cicil emas

Pembiayaan gadai dan cicil emas terobosan Bank Syariah Mandiri ini berdasarkan prinsip-prinsip syariah. Pembiayaan gadai adalah pembiayaan kepada nasabah yang diberikan dengan menahan sementara emas yang dijadikan barang gadai 
sampai adanya pelunasan dari pihak nasabah. Sedangkan cicil emas adalah pembiayaan yang akan diperoleh nasabah berupa emas yang akan diserahkan setelah adanya pelunasan dengan cicilan.

d. Pembiayaan Umrah

Pembiayaan umrah merupakan pembiayaan terbaru dari Bank Syariah Mandiri Cabang Padangsidimpuan. Pembiayaan ini diberikan untuk nasabah yang secara umum telah memenuhi setiap prosedur yang ada (Rahmat Pipin, Branch Operation Service Manager BSM Cabang Padangsidimpuan).

\section{Fungsi Jaminan dalam Pembiayaan Mikro}

Jaminan pembiayaan mikro menurut (Ady Syahputra, micro analyst BSM Cabang Padangsidimpuan) adalah second way dari pemberian pembiayaan. Sebab beliau mengetahui bahwa secara teori fiqh jaminan itu tidak diperbolehkan. Namun, melihat kondisi orang Indonesia pada saat ini memaksa setiap bidang perbankan membuat ketentuan berdasarkan peraturan yang dibuat oleh Bank Indonesia untuk menetapkan jaminan terhadap pembiayaan apapun.

Konsep kehati-hatian yang dilakukan Bank Syariah Mandiri dengan menetapkan jaminan akan sedikit mengurangi risiko apabila ada pembiayaan yang sengaja bermasalah oleh nasabah (Ady Syahputra, Micro Analyst BSM Cabang Padangsidimpuan).

\section{Pembiayaan Bermasalah}

Pembiayaan bermasalah adalah pembiayaan yang sudah masuk dalam kollektibilitas empat dan lima. Pembiayaan tidak lepas dari adanya pemicu terjadinya masalah. Karena, nasabah juga manusia yang tidak akan luput dari kesalahan. Yang artinya nasabah sendiri dapat menjadi pemicu terjadinya pembiayaan bermasalah baik disengaja maupun tidak disengaja. Berikut adalah jumlah pembiayaan mikro yang ada di Bank Syariah Mandiri Cabang Padangsidimpuan mulai Tahun 2013-2016:

\section{Tabel 2}

Jumlah Nasabah Pembiayaan Mikro

\begin{tabular}{|c|c|c|}
\hline No & Tahun & $\begin{array}{c}\text { Jumlah Nasabah } \\
\text { Pembiayaan Mikro }\end{array}$ \\
\hline 1 & 2013 & 63 orang \\
\hline 2 & 2014 & 115 orang \\
\hline 3 & 2015 & 180 orang \\
\hline 4 & 2016 & 23o orang \\
\hline
\end{tabular}

Sumber: Bank Syariah Mandiri Cabang Padangsidimpuan, data diolah 
Dilihat dari jumlah nasabah pembiayaan diatas, tampak jelas pembiayaan untuk warung mikro mengalami peningkatan dari tahun ke tahun. Untuk tabel berikutnya peneliti memuat jumlah nasabah yang terkena pembiayaan bermasalah.

\section{Tabel 3}

Jumlah Nasabah Pembiayaan Bermasalah

\begin{tabular}{|c|c|c|}
\hline No & Tahun & $\begin{array}{c}\text { Jumlah nasabah } \\
\text { pembiayaan bermasalah }\end{array}$ \\
\hline 1 & 2013 & 17 orang \\
\hline 2 & 2014 & 50 orang \\
\hline 3 & 2015 & 98 orang \\
\hline 4 & 2016 & 132 orang \\
\hline
\end{tabular}

Sumber: Bank Syariah Mandiri Cabang Padangsidimpuan, data diolah

Selain jumlah nasabah pembiayaan yang meningkat, ternyata jumlah pembiayaan bermasalah terus bertambah seiring berjalannya waktu. Kedua tabel tersebut menunjukkan bahwa jaminan sangat perlu apabila nasabah tidak dapat melunasi kewajibannya.

\section{Penyelamatan dan Penyelesaian Pembiayaan Bermasalah}

Penyelamatan pembiayaan adalah upaya yang dilakukan bank dalam rangka membantu nasabah agar dapat menyelesaikan kewajibannya, yaitu melalui penjadwalan kembali, persyaratan kembali dan penataan kembali.

Resktrukturisasi adalah terminologi keuangan yang banyak digunakan dalam perbankan, yang artinya adalah upaya perbaikan yang dilakukan dalam kegiatan pembiayaan terhadap nasabah yang mengalami kesulitan untuk memenuhi kewajibannya. Resktrukturisasi adalah penyelesaian yang biasa digunakan oleh Bank Syariah Mandiri Cabang Padangsidimpuan.

Restrukturisasi pembiayaan bertujuan untuk penyelamatan pembiayaan sekaligus menyelamatkan usaha debitur agar kembali sehat. Restrukturisasi pembiayaan dapat dilakukan apabila bank mempunyai keyakinan bahwa nasabah:

a. Masih mempunyai itikad baik dalam melunasi kewajibannya.

b. Usahanya masih dapat dipertahankan dengan baik.

c. Tidak sengaja dalam melunasi kewajiban, karena keadaan keuangan yang membuat nasabah menjadi nunggak bayar.

Berdasarkan poin penyelamatan di atas maka untuk proses selanjutnya yaitu penyelesaian masalah dengan adanya perlelangan barang agunan jika restrukturisasi tidak juga menjadi solusi bagi nasabah kollektibilitas.

1) Penyelesaian masalah oleh Account Maintenance

Penyelesaian dengan tahap ini adalah penyelesaian dengan menghilangkan jejak dari nasabah. maksudnya adalah nasabah akan terkena Write Off. Nasabah jenis 
PROSES PENYELAMATAN DAN PENYELESAIAN PEMBIAYAAN BERMASALAH DENGAN

ANALISIS JAMINAN (Studi Kasus Di PT Bank Syariah Mandiri Cabang Padangsidimpuan)

Arti Damisa

ini adalah nasabah yang sama sekali tidak dapat dibantu lagi dalam restrukturisasi. Dalam BI Checking nasabah tidak tampak lagi sebagai nasabah kollektibilitas lima.

Jika bisa digolongkan Write Off untuk nasabah ini adalah kollektibilitas enam.

Nasabah akan berurusan langsung dengan Account Maintenance. Secara tidak langsung nasabah tidak lagi berurusan dengan bank. Tetapi langsung pada Account Maintenance yang telah melakukan Write Off.

2) Penyelesaian Pembiayaan Bermasalah dengan Lelang

Istilah "Lelang” berasal dari bahasa latin “autio" yang berarti peningkatan harga secara bertahap. Lelang adalah proses membeli dan menjual barang atau jasa dengan cara menawarkan harga lebih tinggi dan kemudian menjual barang kepada penawar harga tertinggi. Lelang telah dikenal sejak 450 tahun sebelum Masehi. Di Indonesia lelang secara resmi dikenal pada tahun 1908 dengan berlakunya Vendu reglement (peraturan Lelang). Barang yang dilelang akta jual beli tanah yang sudah disahkan oleh kantor pertanahan. Sebagaimana hanya Institusi yang belabel syariah yang melakukan ini (Samsul Bahri, Account Maintenance BSM Cabang Padangsidimpuan).

\section{KESIMPULAN}

Berdasarkan analisis yang peneliti kemukakan pada bab sebelumnya. Maka peneliti dapat menarik kesimpulan bahwa analisis pembiayaan pada Bank Syariah Mandiri Cabang Padangsidimpuan terlihat belum efektif. Jika dilihat dari pembiayaan bermasalah yang terjadi pada setiap tahunnya. Padahal dalam upaya untuk mencegah terjadinya pembiayaan bermasalah sudah sangat baik. Adapun cara yang dilakukan untuk menganalisis jaminan jika terjadi pembiayaan bermasalah, yaitu: melakukan survey lapangan ke alamat objek jaminan, analisa jaminan oleh Account Maintenance dengan membuat nasabah menjadi Write Off, dan analisis jaminan oleh Badan Perlelangan Nasional. Dengan demikian, Peneliti menyimpulkan bahwa Bank Syariah Mandiri Cabang Padangsidimpuan dalam menganalisis jaminan sudah lebih efektif dari teori-teori yang ada. Bahkan Bank Syariah Mandiri Cabang Padangsidimpuan lebih dalam mengkaji soal jaminan ini. Jaminan yang dimaksudkan harus marketable dan hal itu juga dilakukan dilapangan. Sebab jika tidak bank sendiri yang akan menanggung akibatnya.

\section{DAFTAR PUSTAKA}

Bungin, Burhan, 2010, Data Penelitian Kualitatif, Jakarta: PT RajaGrafindo Persada.

Departemen Pendidikan dan Kebudayaan, 2011, Kamus Besar Bahasa Indonesia, Edisi ketiga, Jakarta: Balai Pustaka.

Ikatan Bankir Indonesia,2015, Mengelola Pembiayaan Bank Syariah ,Jakarta: PT Gramedia Pustaka Utama. 
Karim, Adiwarman, 2009, Bank Islam: Analisis Fiqh dan Keuangan, Jakarta: Rajawali Pers. , Adiwarman,2011, Bank Islam Analisis Fiqih Dan Keuangan, Jakarta: PT RajaGrafindo Persada.

Moleong, J, Lexy,2004, Metode Penelitian Kualitatif, Bandung: PT Remaja Rosdakarya.

Muhammad, 2008, Manajemen Pembiayaan Mudharabah di Bank Syariah, Jakarta: Rajawali. , 2014, Manajemen Dana Bank Syariah, Yogyakarta: PT Raja Grafindo Persada.

Rivai, Veithzal dan Veithzal, Permata, Andria, 2008, Islamic Financial Management, Jakarta: PT RajaGrafindo Persada.

Sutedi, Adrian,2009, Perbankan Syariah Tinjauan Dan Beberapa Segi Hukum , Bogor: Ghalia Indonesia.

Suwiknyo, Dwi, 2009, Kamus Lengkap Ekonomi Islam, Yogyakarta: Total Media.

Undang-Undang Republik Indonesia Nomor 21 Tahun 2008 Tentang Perbankan Syariah. 